\title{
Differential Expression of VEGFA, TIE2, and ANG2 but not ADAMTS1 in Rat Mesenteric Microvascular Arteries and Veins
}

\author{
N. MECHA DISASSA ${ }^{1^{*}}$, B. STYP-REKOWSKA ${ }^{1^{*}}$, B. HINZ $^{1}$, L. DA SILVA-AZEVEDO ${ }^{1}$, \\ A. R. PRIES ${ }^{1,2}$, A. ZAKRZEWICZ ${ }^{1}$ \\ * Authors contributed equally.
}

${ }^{1}$ Department of Physiology, Charité Berlin, Berlin, ${ }^{2}$ Deutsches Herzzentrum Berlin, Berlin, Germany

Received September 19, 2007

Accepted February 1, 2008

On-line April 1, 2008

\begin{abstract}
Summary
Microvessels respond to metabolic stimuli (e.g. $\mathrm{pO}_{2}$ ) and hemodynamic forces (e.g. shear stress and wall stress) with structural adaptations including angiogenesis, remodeling and pruning. These responses could be mediated by differential gene expression in endothelial and smooth muscle cells. Therefore, rat mesenteric arteries and veins were excised by microsurgery, and mRNA expression of four angioadaptation-related genes was quantified by real time duplex RT-PCR in equal amounts of total RNA, correlated to two different house keeping genes (B-actin, GAPDH). The results show higher expression of VEGFA, TIE2, and ANG2 in arteries than in veins, but equal expression of ADAMTS1. Higher availability of VEGFA mRNA in endothelial cells of arteries shown here could contribute to the maintenance of mechanically stressed blood vessels and counteract pressureinduced vasoconstriction.
\end{abstract}

\section{Key words}

Microcirculation • Endothelial cells • Vascular Endothelial Growth Factor A • Receptor TIE2 • Angiopoietin-2

\section{Corresponding author}

A. Zakrzewicz, Charité Berlin, Campus Benjamin Franklin, Department of Physiology, Arnimallee 22, D-14195 Berlin, Germany. Fax: +49-30 84451634 .

E-mail: andreas.zakrzewicz@charite.de

\section{Introduction}

In order to understand the mechanisms underlying angioadaptive processes (Zakrzewicz et al.
2002) including angiogenesis, vascular remodeling, and pruning several functional parameters, e.g. shear stress, oxygen saturation, red blood cell velocity, vessel diameter or capillary density have been measured in individual microvessels by intravital microscopy (IVM) in vivo (Hudlicka et al. 1986, Andresen et al. 1994, Pries et al. 1995a, 1998, 2005, Skalak and Price 1996, Fath et al. 1998, Tuttle et al. 2002a,b, Bakker et al. 2003, Skalak 2005). To understand the observed vascular reactions, information on gene expression is important. Recent studies on endothelial gene expression demonstrated shear stress-dependent induction of the endothelial receptor tyrosine kinase TIE2 and its phosphorylation (Chen et al. 2001, Lee and Koh 2003, Chlench et al. 2007). Furthermore, ADAMTS1 (a disintegrin-like and metalloprotease with thrombospondin motifs-1) (Bongrazio et al. 2000) and VEGFA (vascular endothelial growth factor) have been reported to be shear stress-inducible in some experimental models (Da Silva-Azevedo et al. 2002, Rivilis et al. 2002, Baum et al. 2004, Williams et al. 2006), while ANG2 (angiopoietin-2) was suppressed by shear stress in endothelial cells in vitro (Chlench et al. 2007, Goettsch et al. 2008). Since the mean shear stress in arteries is an order of a magnitude higher than that in veins (Pries et al. 1995b, Pries et al. 2005), these results would predict higher expression of TIE2, ADAMTS1 and VEGFA in arteries compared to veins, while ANG2 should be suppressed. This would be most important for smaller arteries, which can be involved either in precapillary tone regulation or in angiogenesis. 


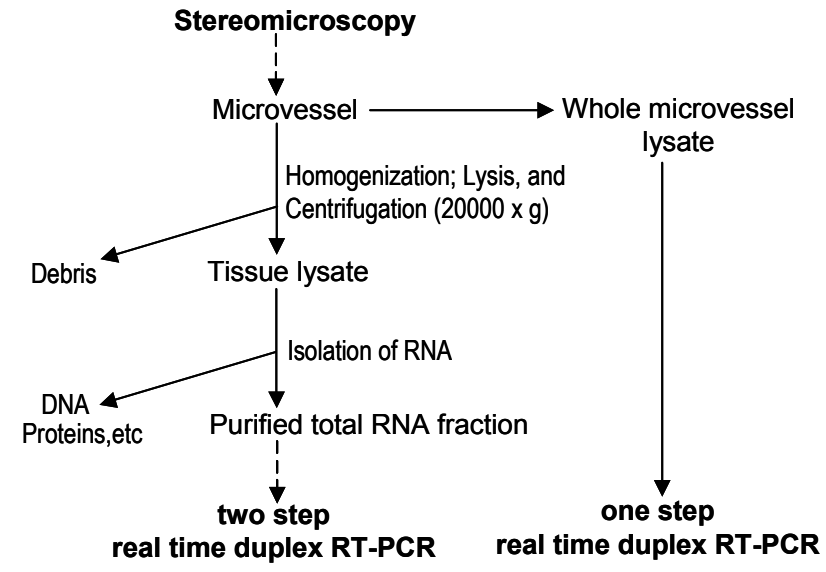

Fig. 1. Schematic outline of the two alternative procedures used to obtain RNA from single mesenteric microvessels for amplification of specific mRNA by real time duplex-RT-PCR. For details see the text.

However, gene expression studies of single vessel segments are rare. In the present study, we obtained histometrically characterized microvascular arteries and their accompanying veins by microsurgery and analyzed the expression of aforementioned genes by real time RT-PCR techniques.

\section{Materials and Methods}

\section{Animals and excision of vessel segments}

After obtaining approval from the university and state authorities for animal welfare, male Sprague Dawley rats (250-350 g) were anesthetized with urethane $(1.5 \mathrm{~g} / \mathrm{kg}$ body weight $)$ and ketamine $(0.5 \mathrm{ml} / \mathrm{kg}$ body weight). The mesentery was rolled out of the abdominal cavity, and placed on a stage under a stereomicroscope. Single microvascular mesenteric arteries and veins were freed from the adventitia and then excised with a length of about $10 \mathrm{~mm}$ under stereomicroscopic control. The vessels were collected in separate $0.2 \mathrm{ml}$ Eppendorf tubes, immediately frozen in liquid nitrogen, and stored at $-80{ }^{\circ} \mathrm{C}$ until use. Alternatively, vessels were taken together with surrounding tissue for histometric analysis as described below. Animals were sacrificed by $\mathrm{KCl}$ injection.

\section{Isolation of RNA from microvessels}

Total RNA was isolated from the flow-through tissue lysates using a commercially available RNA isolation and purification kit (RNeasy Micro Kit, Qiagen, Hilden, Germany) according to the manufacturer's instructions. Briefly, $350 \mu \mathrm{l}$ of lysis buffer (RLT including 2-mercaptoethanol; RNeasy Micro Kit, Qiagen, Hilden, Germany) and RNasin at a final concentration of $1 \mathrm{U} / \mu \mathrm{l}$ (Promega, WI, USA) were added to flash frozen microvascular blood vessel segments. Thorough homogenization of the samples was achieved using a teflon pestle (Schütt, Göttingen, Germany) in $1.5 \mathrm{ml}$ Eppendorf tubes followed by centrifugation ( $2 \mathrm{~min}$ at $20,000 \times \mathrm{g}$ ) through a spin column (QIAshredder, Qiagen, Hilden, Germany), and flow-through was used for extraction of RNA. RNA concentrations were determined using the RiboGreen RNA quantitation Kit (Invitrogen, CA, USA) for low concentrations according to the manufacturer's protocol. Isolated RNA was then analyzed in a two steps approach as described in the text below (Fig. 1).

\section{Quantitative real time $\mathbf{R}$ T-PCR}

Design of primers and probes

Gene-specific primers were generated for six genes: VEGFA, ANG2, TIE2, ADAMTS1, and the housekeeping genes $\beta$-actin and GAPDH. Exonboundaries spanning primers (18-25 nucleotides; Table $1)$, which do not bind to genomic DNA, and with melting temperatures (Tm) between $58{ }^{\circ} \mathrm{C}$ and $62{ }^{\circ} \mathrm{C}$ were designed for amplification specific target genes using a publicly available genome data base (NCBI, MD, USA) and the Primer3 software (Whitehead Institute for Biomedical Research, MA, USA). The primers were manufactured by MWG (Ebersberg, Germany). PCR-probes (Table 1) were designed to exhibit a Tm 8-10 ${ }^{\circ} \mathrm{C}$ higher than that of the corresponding primers using the gene data base and software mentioned above, manufactured by Operon Biotechnologies (Köln, Germany), and labeled at 5'end with the fluorophores FAM, JOE, TET or HEX and with the quencher BHQ at 3 'end.

\section{Real time RT-PCR}

a) Amplification of $m R N A$ from microvessel segments: one-step approach

mRNA was amplified directly from shockfrozen vessel segments without prior extraction of RNA using the respective forward inner primer for reverse transcription (Table 1). Accordingly, a single vessel segment was flash frozen in liquid nitrogen and taken directly as a template for real time duplex RT-PCR, carried out in a total reaction volume of $25 \mu 1$ as described below (Fig. 1). 
Table 1. Sequences of primers and probes.

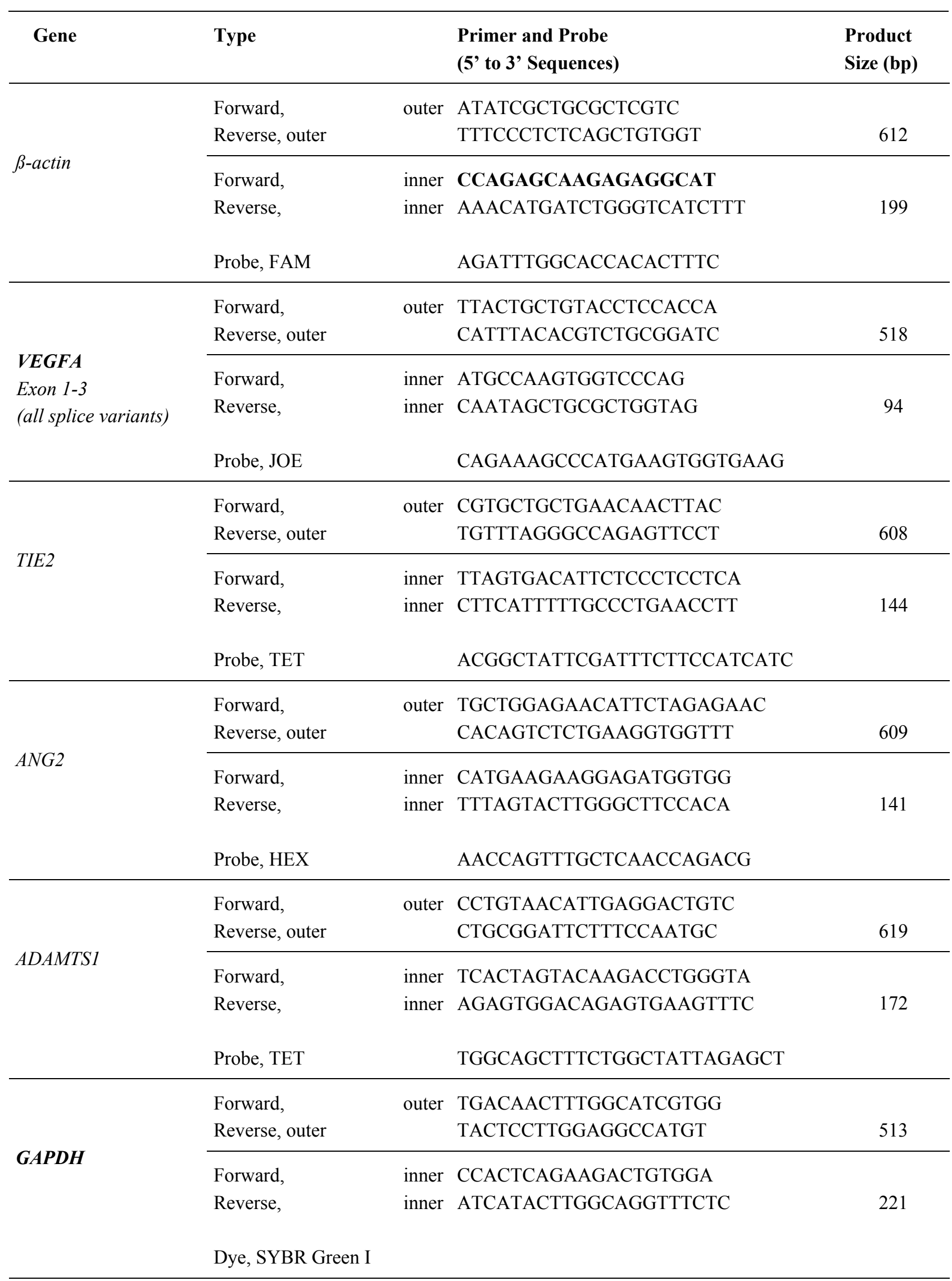


b) Amplification of $m R N A$ from microvessel segments: two steps approach

$4 \mathrm{ng}$ of total-RNA were used for reverse transcription of mRNA with the sensiscript reverse transcription kit (Qiagen, Hilden, Germany) using oligodT (Promega, WI, USA) as primer. Reaction mixtures were incubated at $37{ }^{\circ} \mathrm{C}$ for 1 hour. Single real-time PCR was carried out in a total volume of $50 \mu \mathrm{l}$ containing $0.4 \mu \mathrm{M}$ of each inner primer (sense and antisense; Table 1), $0.2 \mu \mathrm{M}$ of the respective dual labeled probe, $10 \mu \mathrm{l}$ template cDNA (corresponding to $2 \mathrm{ng}$ of total RNA) and $25 \mu \mathrm{l}$ multiplex mix (QuantiTect $^{\circledR}$ Multiplex PCR Kit, Qiagen, Hilden, Germany). For duplex RT-PCR two primer sets were simultaneously used. PCR was run with an initial activation step at $95{ }^{\circ} \mathrm{C}$ for $15 \mathrm{~min}$, followed by 45 cycles with a denaturation step at $94{ }^{\circ} \mathrm{C}$ for $60 \mathrm{~s}$ and a combined annealing and elongation step at $60{ }^{\circ} \mathrm{C}$ for $60 \mathrm{~s}$ according to the manufacturer's instructions (QuantiTect $^{\circledR}$, Qiagen, Hilden, Germany) using a real time cycler (Rotor Gene 2000, LTF, Wasserburg, Germany). Non-RT and non-template controls were run for all amplification reactions. All PCR products were controlled by melting curves and product sizes confirmed by agarose gel electrophoresis.

Separate amplification reactions for GAPDH were performed in a final volume of $20 \mu \mathrm{l}$, containing cDNA samples corresponding to 2 ng of total RNA as a template, primers for GAPDH at a final concentration of $0.3 \mu \mathrm{M}$, and $10 \mu \mathrm{l}$ Master mix SYBR-Green (QuantiTect SYBR Green I PCR Kit, Qiagen, Hilden, Germany). PCR was performed using a Rotor Gene 2000 cycler (LTF, Wasserburg, Germany) at $94{ }^{\circ} \mathrm{C}$ for $900 \mathrm{~s}$, followed by 45 cycles at $94{ }^{\circ} \mathrm{C}$ for $15 \mathrm{~s}, 56{ }^{\circ} \mathrm{C}$ for $30 \mathrm{~s}$, and $72{ }^{\circ} \mathrm{C}$ for $75 \mathrm{~s}$. Amplification products were controlled by melting curves. Non-RT and non-template controls were run for all reactions.

\section{External standards}

Isolation of rat liver RNA was performed using a commercially available Kit (RNeasy Mini Kit, Qiagen, Hilden, Germany). Two $\mu \mathrm{g}$ rat liver RNA was reverse transcribed $\left(70{ }^{\circ} \mathrm{C}\right.$ for $8 \mathrm{~min}$, and $42{ }^{\circ} \mathrm{C}$ for $1 \mathrm{~h}$, in a total volume of $25 \mu \mathrm{l})$ with oligo(dT) primer and $200 \mathrm{U}$ M-MLV reverse transcriptase (Promega, WI, USA). The resulting cDNA was used for amplification of specific sequences (500-700 bp) which included the shorter sequences of target genes described above using appropriate pairs of outer primers (Table 1) with $1 \mathrm{U}$
Taq DNA polymerase (Promega, WI, USA). The amplicons were purified (MinElute purification Kit; Qiagen, Hilden, Germany) and used as external standard in real time simplex and duplex RT-PCR, with the same conditions stated above.

\section{Excluding amplification of genomic DNA}

DNA (DNeasy kit, Qiagen) and RNA (RNeasy kit, Qiagen) were isolated from liver tissue, according to the protocol of the manufacturer, photometrically quantified (GeneQuant, Amersham pharmacia biotech, Cambridge, UK), and the PCR performed as described above. To exclude the amplification of genomic DNA, which is especially important during the one-step approach, all intron-exon-spanning primers were tested using genomic DNA (200 ng) as a PCR template and compared with the same amount of RNA (200 ng). No PCR products were generated from genomic DNA using the primers shown in Table 1 (data not shown).

\section{Histology}

Segmental mesenteric arteries and veins were excised, embedded in Tissue-Tek (O.T.C. compound, Sakura, USA), and kept at $-20{ }^{\circ} \mathrm{C}$ until cryosection was performed. $30 \mu \mathrm{m}$ cross-sections were placed on slides and transferred to $4 \%$ formalin in PBS at room temperature. Vessels were stained with $0.5 \%$ eosin for $30 \mathrm{~s}$, washed gently with distilled water, incubated for $90 \mathrm{~s}$ with methylene blue, dehydrated with $70 \%, 96 \%$ and $100 \%$ ethanol for 1 min each, embedded in Euparal (Carl Roth, Germany), and covered with coverslips. The histological slides were observed under a transillumination microscope (Ortholux, Leitz; Germany; objective 25/0.60). The inner circumference and the thickness of endothelial and smooth muscle cell layers of arteries and veins were measured from the images observed under the transillumination microscope, taken by a digital camera and using an image analysis system (Pries et al. 1997), calibrated to a standard scale taken under the same optical conditions.

\section{Statistics}

Data are presented as mean \pm S.E.M. if not otherwise stated. Comparison of data sets was performed by Student's t-test for unpaired samples if applicable. Statistical significance was assessed at $p \leq 0.05$. Measurements were done in duplicate and " $n$ " refers to the number of blood vessels in each group. 
Table 2. Morphological parameters of analyzed arteries and veins in the mesentery $(n=4$, mean \pm S.D. $)$.

\begin{tabular}{|c|c|c|}
\hline & arteries & veins \\
\hline \multicolumn{3}{|l|}{ Vessel size $[\mu m]$} \\
\hline Inner circumference & $623 \pm 11.1$ & $1044 \pm 112.4$ \\
\hline Diameter & $246 \pm 3.2$ & $348 \pm 35.8$ \\
\hline \multicolumn{3}{|c|}{ Vessel wall thickness $[\mu m]$} \\
\hline Total & $24.0 \pm 2.7$ & $8.1 \pm 0.4$ \\
\hline Endothelium & $2.0 \pm 0.3$ & $2.1 \pm 0.1$ \\
\hline Smooth muscle & $22.0 \pm 2.4$ & $6.0 \pm 0.3$ \\
\hline \multicolumn{3}{|c|}{ Vessel wall cross-sectional area $\left[\mu m^{2} .10^{3}\right]$} \\
\hline Total & $16.7 \pm 2.2$ & $8.6 \pm 1.0$ \\
\hline Endothelium & $1.3 \pm 0.2$ & $2.1 \pm 0.3$ \\
\hline Smooth muscle & $15.5 \pm 2.1$ & $6.5 \pm 0.8$ \\
\hline
\end{tabular}

\section{Results}

Morphological characteristics of mesenteric arteries and their accompanying veins

Table 2 represents morphological characteristics of the investigated vessels. The thickness of the endothelium in arteries and veins was equal. As expected, arteries exhibited a 4-fold thicker smooth muscle cell layer as compared to their accompanying veins. With respect to the total cross-sectional area of the whole vessel wall, the relative contribution of endothelial cells is approximately 0.24 in veins and 0.07 in arteries, respectively.

\section{Gene expression in arteries and veins}

For the investigated genes a high correlation between $\mathrm{Ct}$-values and copy numbers was observed for both simplex and duplex PCR (Fig. 2A). The same standardization was performed for all genes analyzed in the present study exhibiting $\mathrm{r}^{2}$ values above 0.95 in all cases.

In order to reduce any loss of RNA during isolation and purification, a one-step approach similar to that in single cell PCR was chosen as described in the Methods (Fig. 1). However, using this procedure, measurements showed extremely high variations (Fig. 2B). This was greatly reduced by a two-step approach including purification and quantification of isolated total RNA (Fig. 2B).

The gene expression levels of four genes were

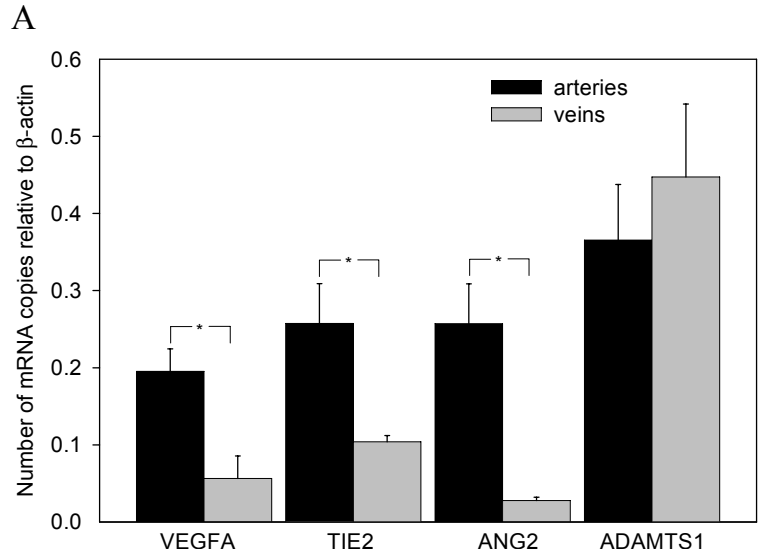

B

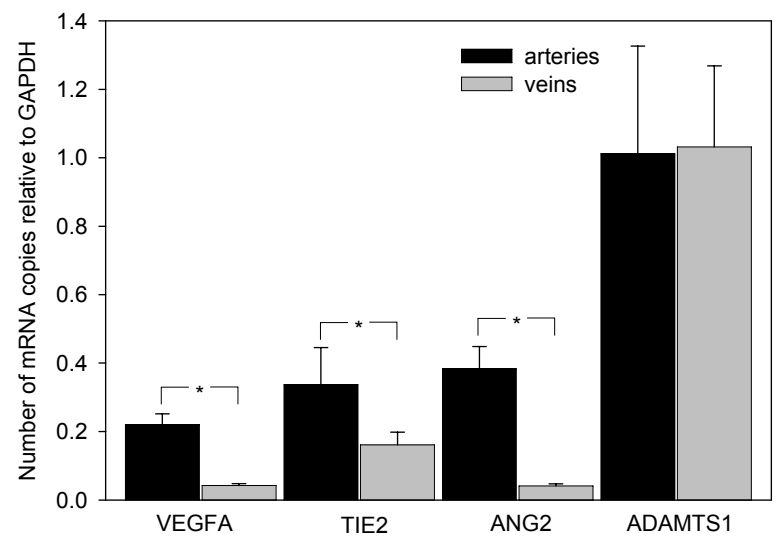

Fig. 3. Expression profiles of four genes in arteries and veins. The copy numbers of VEGFA-, Tie2-, ANG2- or ADAMTS1 mRNA are given relative to that of $B$-actin (A, upper panel) and GAPDH (B, lower panel) as a house keeping gene. Data are given as mean \pm S.E.M., $\mathrm{n}=11 . * \mathrm{p} \leq 0.05$.

compared between arteries and veins (Fig. 3). Values are given as quotients of the copy number of the gene of interest relative to that of $\beta$-actin as house keeping gene measured by duplex RT-PCR (Fig. 3A). In addition, all measured values were normalized to a second house keeping gene GAPDH (Fig. 3B). The expression of VEGFA, TIE2, and ANG2 was higher in arteries compared to veins, while ADAMTS1 was equally expressed in both vessel types.

\section{Discussion}

In this study, the expression of four genes related to angioadaptation and vascular remodeling has been quantified for paired microvascular arteries and veins using $\beta$-actin or GAPDH as house keeping genes. The results show higher expression of VEGFA, TIE2, and ANG2 in arteries as compared to veins, but equal expression of ADAMTS1. 
A
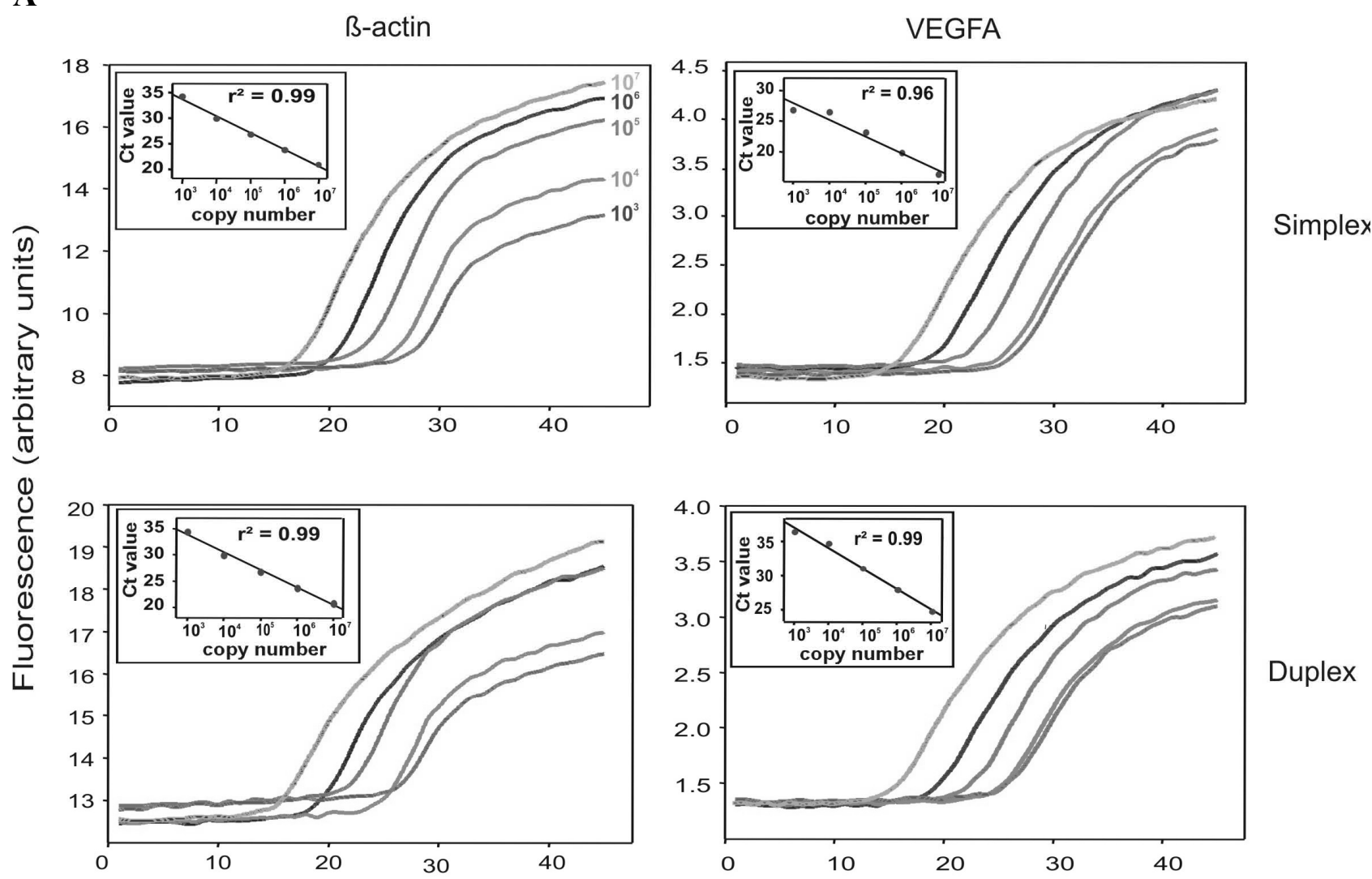

Cycle number

B

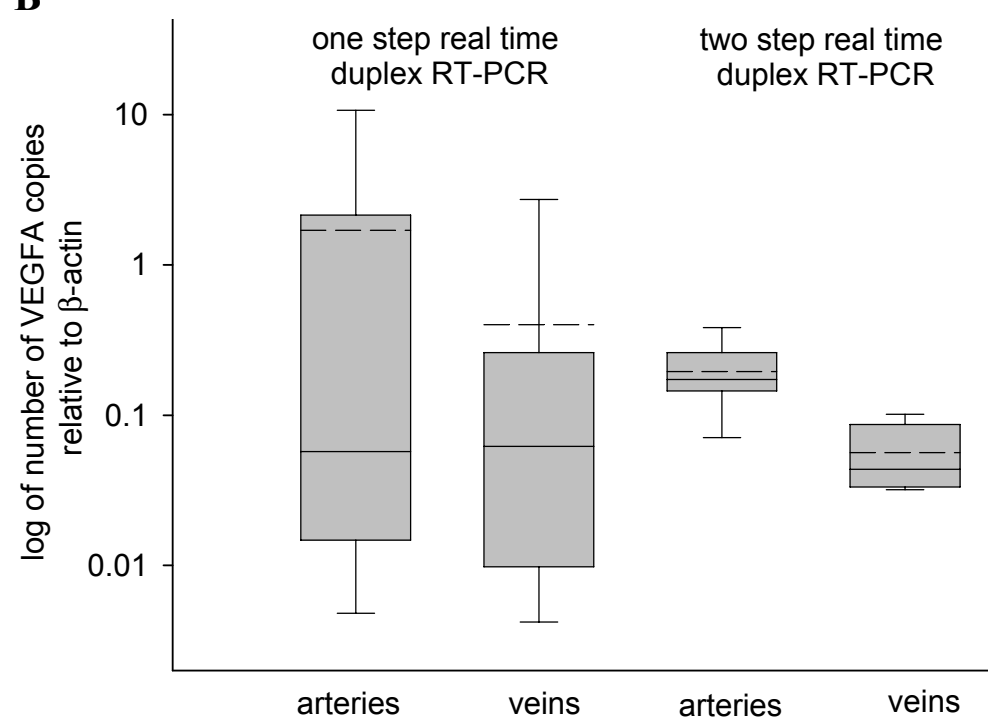

Fig. 2. A: Simplex- and Duplex-real time RT-PCR reveal similar results. RT-PCR was performed with total RNA to produce standard-cDNA for genes of interest. Tenfold serial dilutions of standard-cDNA ranging from $10^{7}$ to $10^{3}$ copies/assay were amplified to produce standard curves shown as inserts for Bactin (as a house keeping gene; left) and VEGFA (as an example for a gene of interest; right). B: The two step approach is better than the one step approach. Expression of VEGFA relative to $\beta$-actin was determined by duplex RT-PCR from whole microvessel lysates ( $n=12$; left, one step approach) or purified total RNA fraction ( $n=11$, right, two step approach). Box plots represent the $10^{\text {th }}, 25^{\text {th }}, 75^{\text {th }}$, and $90^{\text {th }}$ percentiles, the median (solid line) and the mean (dashed line) value.

Arteries and veins of the rat mesentery differ in the hemodynamic and metabolic conditions to which they are exposed. The magnitude of wall shear stress in the mesentery of the rat is lower in veins $\left(\approx 15 \mathrm{dyn} / \mathrm{cm}^{2}\right)$ than in arteries $\left(\approx 90 \mathrm{dyn} / \mathrm{cm}^{2}\right.$ ) (Pries et al. $1995 \mathrm{~b}$, Pries et al. 2005). Furthermore, oxygen saturation measured during intravital microscopy has been reported to be $98 \%$ in arteries and $76 \%$ in veins in the mesentery of rats
(Styp-Rekowska et al. 2007). From this, an oxygen tension can be estimated of about $100 \mathrm{mmHg}$ for arteries and of about $50 \mathrm{mmHg}$ for veins. These significant hemodynamic and metabolic differences could play a role in differential gene expression between arteries and veins under steady-state conditions.

Analyzing gene expression in single segments of microvessels still remains to be a challenge for two 
reasons, the amount of mRNA derived from each sample is relatively low (and the protein content not sufficient for immunoblotting), and the vessel wall consists of more than one cell type. We took advantage from real time RTPCR techniques to quantify even low copy numbers of mRNA. Most often, the amount of RNA, isolated from a single microvessel segment, was enough for one or two PCRs only.

The amplification of mRNA directly from shock-frozen microvessel segments using intron-exonspanning primers without RNA isolation by real time RTPCR to reduce any loss of mRNA by the isolation techniques showed comparable results, but with extremely variable values (Fig. 2, panel B, left). It is evident from these results, that further RNA isolation and purification is necessary to obtain reproducible values of gene expression (Fig. 2, panel B, right) from single segments of microvessels. The resulting protocol describes reduction of the coefficient of variation $(\mathrm{CV})$ from about $200 \%$ to about $45 \%$. Thus, elaborate isolation and purification steps seem to be necessary, especially for small but complex tissue samples.

VEGFA mRNA was about two- to fourfold higher in arteries than in veins. VEGFA mRNA can be produced by both endothelial as well as smooth muscle cells, but its effects are restricted to the endothelium, because VEGFA-receptors are expressed on endothelial but not smooth muscle cells. The amount of VEGFA which is probably available per endothelial cell will even be higher in arteries, since the relative contribution of endothelial cells to arterial walls is lower than to venular walls. VEGFA is a main inducer of sprouting type angiogenesis (Ferrara et al. 2003), and tip cell guidance (Gerhardt et al. 2003). In addition, maintenance of blood vessels (Lee et al. 2007), vascular permeability (Guidi et al. 1995) and dilation of blood vessels (Ku et al. 1993) can be enhanced by VEGFA. Consequently, the pharmacological lowering of active VEGFA concentrations is accompanied by an increase in blood pressure in some patients (Hurwitz et al. 2004). Since mature arteries do not sprout and they have relatively low permeability during steady-state conditions, the most relevant biological function of higher amounts of VEGFA mRNA copies in arteries, found in this study, should be vasodilation, counterbalancing the Bayliss' effect. This may be supported by our previous finding, that eNOSknockout mice, lacking endothelial $\mathrm{NO}$ as a main vasodilator, show an increased endothelial baseline VEGFA concentration (Da Silva-Azevedo et al. 2002,
Baum et al. 2004).

Hypoxia is well known as a main inducer of VEGFA expression. Because oxygen tension is higher in arteries than in veins, this cannot explain the differences observed. On the other hand, endothelial VEGFA expression can be induced by shear stress in vitro (Chen et al. 2001, Fong et al. 2005) and with enhanced wall shear stress during prazosin treatment of mice in vivo (Da Silva-Azevedo et al. 2002), during which the VEGFA concentration in the surrounding tissue declined (Baum et al. 2004). So, higher shear stress could be an explanation for higher amounts of VEGFA mRNA in arteries. Since shear stress induces VEGFA in endothelial cells mainly, it should then work in an autocrine fashion. Endothelial autocrine VEGFA effects have indeed recently been shown to be necessary for blood vessel maintenance rather than for the induction of sprouting type angiogenesis (Lee et al. 2007). Thus our results could indicate that (for some unknown reason) arteries need stronger signals for their maintenance than veins. However, the complex interaction of different cell types in a vessel wall in vivo may further contribute to a differential gene expression.

mRNA expression of endothelial tyrosine kinase receptor TIE2 was about twofold higher in arteries compared to veins. Since TIE2 is known to be specifically expressed in endothelial cells (Dumont $e t$ al. 1993), its expression could be correlated to the relative contribution of endothelial cells to different types of blood vessel walls (Table 2). Correlated to endothelial cells, the expression of TIE2 mRNA would be even seven times higher in arteries compared to veins. The observed differences between arteries and veins must be caused by differences between their endothelial cells. Endothelial cells are directly exposed to shear stress - frictional forces exerted by the flowing blood. Thus, higher expression of TIE2 mRNA in arteries might be in agreement with our previous finding, that the expression of TIE2 is induced by shear stress in endothelial cells in vitro (Chlench et al. 2007) and could contribute to the stabilization of arterial walls, since the activation of TIE2 (or the inhibition of ANG2 respectively) has been shown to stimulate the recruitment of perivascular cells (Maisonpierre et al. 1997) and vessel wall maturation (Jain 2003). However, the endogenous TIE2-antagonist ANG2 was also more expressed in arteries than in veins, and could thus compensate for the induction of TIE2. However, in some situations, ANG2 has been shown to be an activator of TIE2-dependent signal transduction, 
especially at higher concentrations (Daly et al. 2006). So, higher expression of ANG2 is not necessarily linked to the antagonism of TIE2 effects. Nevertheless, higher expression of ANG2 in arteries was completely unexpected, since its expression can be suppressed by shear stress in vitro (Chlench et al. 2007). Alternatively, induction of ANG2 can be achieved by hypoxia (Mandriota and Pepper 1998), but this again would not explain its prevalence in arteries. ANG2 has been shown to be stored in Weibel-Palade bodies (Fiedler et al. 2004) which were originally described in arterial endothelial cells (Weibel and Palade 1964). This would probably explain or at least correlate with a higher amount of ANG2 mRNA in arteries. However, some authors reported higher numbers of Weibel-Palade bodies in veins than in arteries (Yamamoto et al. 1998). Most probably, higher copy numbers of ANG2 mRNA in arteries will be due to a contribution of smooth muscle cells. Since ANG2 has recently been shown to be a significant cofactor of TNF $\alpha$-induced inflammatory reactions (Fiedler et al. 2006), it could contribute to the development of atherosclerosis. Furthermore, a higher expression of ANG2 in arteries compared to veins as shown in this study could contribute to the restriction of atherogenesis to arteries.

ADAMTS1, although induced by shear stress in endothelial cells (Bongrazio et al. 2000), was found to be equally expressed in arteries and veins. In cultured human endothelial cells without flow, ADAMTS1 is nearly completely suppressed. If these cells are exposed to increasing amounts of shear stress (up to $6 \mathrm{dyn} / \mathrm{cm}^{2}$ ), its expression is induced (Zakrzewicz et al. 2006). However, shear stress in the microcirculation of the rat is significantly higher. Thus, from the data reported here, we have to assume, that the shear stress-induced expression of ADAMTS1 reaches a plateau somewhat below the typical wall shear stress in the veins tested, so that there is no further increase produced by the higher shear stress in arteries. By the release of anti-angiogenic peptides from thrombospondin (Lee et al. 2006), ADAMTS1 could inhibit vascular sprouting from well perfused, mature blood vessels of every type.

Several studies identified arterial-venous differentiation markers in endothelial cells like EphB4 for instance (Wang et al. 1998). However, EphB4 is not a venous specific marker in mesenteric blood vessels of the rat (Taylor et al. 2007). This indicates that arterial-venous differentiation can be accompanied by different marker molecules in different vascular beds. Therefore, the differential expression of endothelial genes has to be tested in single vessel segments from every vascular bed, since the results from one part of the vasculature cannot be necessarily generalized to all vascular regions.

Taken together, microvascular arteries and their accompanying veins differ significantly in the expression of important angioadaptive genes, even during steadystate-conditions. This is probably a part of the physiological adaptation mechanisms of blood vessels to different hemodynamic conditions.

\section{Conflict of Interest}

There is no conflict of interest.

\section{References}

ANDRESEN DM, O'SHAUGHNESSY M, ACLAND RD, ANDERSON GL, SCHUSCKE D, BANIS J, JR, BARKER JH: Direct visualization and measurement of microsurgically induced thromboembolism. Microsurgery 15: 413-420, 1994.

BAKKER EN, VERSLUIS JP, SIPKEMA P, VANTEEFFELEN JW, ROLF TM, SPAAN JA, VANBAVEL E: Differential structural adaptation to haemodynamics along single rat cremaster arterioles. $J$ Physiol Lond $\mathbf{5 4 8}$ : 549-555, 2003.

BAUM O, DA SILVA-AZEVEDO L, WILLERDING G, WOCKEL A, PLANITZER G, GOSSRAU R, PRIES AR, ZAKRZEWICZ A: Endothelial NOS is main mediator for shear stress-dependent angiogenesis in skeletal muscle after prazosin administration. Am J Physiol 287: H2300-H2308, 2004.

BONGRAZIO M, BAUMANN C, ZAKRZEWICZ A, PRIES AR, GAEHTGENS P: Evidence for modulation of genes involved in vascular adaptation by prolonged exposure of endothelial cells to shear stress. Cardiovasc Res 47: 384-393, 2000.

CHEN BP, LI YS, ZHAO Y, CHEN KD, LI S, LAO J, YUAN S, SHYY JY, CHIEN S: DNA microarray analysis of gene expression in endothelial cells in response to 24-h shear stress. Physiol Genomics 7: 55-63, 2001. 
CHLENCH S, MECHA DISASSA N, HOHBERG M, HOFFMANN C, POHLKAMP T, BEYER G, BONGRAZIO M, DA SILVA-AZEVEDO L, BAUM O, PRIES AR, ZAKRZEWICZ A: Regulation of Foxo-1 and the angiopoietin-2/Tie2 system by shear stress. FEBS Lett 581: 673-680, 2007.

DA SILVA-AZEVEDO L, BAUM O, ZAKRZEWICZ A, PRIES AR: Vascular endothelial growth factor is expressed in endothelial cells isolated from skeletal muscles of nitric oxide synthase knockout mice during prazosininduced angiogenesis. Biochem Biophys Res Commun 297: 1270-1276, 2002.

DALY C, PASNIKOWSKI E, BUROVA E, WONG V, ALDRICH TH, GRIFFITHS J, IOFFE E, DALY TJ, FANDL JP, PAPADOPOULOS N, MCDONALD DM, THURSTON G, YANCOPOULOS GD, RUDGE JS: Angiopoietin-2 functions as an autocrine protective factor in stressed endothelial cells. Proc Natl Acad Sci USA 103: 15491-15496, 2006.

DUMONT DJ, GRADWOHL GJ, FONG GH, AUERBACH R, BREITMAN ML: The endothelial-specific receptor tyrosine kinase, tek, is a member of a new subfamily of receptors 47. Oncogene 8: 1293-1301, 1993.

FATH SW, BURKHART HM, MILLER SC, DALSING MC, UNTHANK JL: Wall remodeling after wall shear rate normalization in rat mesenteric arterial collaterals. J Vasc Res 35: 257-264, 1998.

FERRARA N, GERBER HP, LECOUTER J: The biology of VEGF and its receptors. Nat Med 9: 669-676, 2003.

FIEDLER U, SCHARPFENECKER M, KOIDL S, HEGEN A, GRUNOW V, SCHMIDT JM, KRIZ W, THURSTON G, AUGUSTIN HG: The Tie-2 ligand angiopoietin-2 is stored in and rapidly released upon stimulation from endothelial cell Weibel-Palade bodies. Blood 103: 4150-4156, 2004.

FIEDLER U, REISS Y, SCHARPFENECKER M, GRUNOW V, KOIDL S, THURSTON G, GALE NW, WITZENRATH M, ROSSEAU S, SUTTORP N, SOBKE A, HERRMANN M, PREISSNER KT, VAJKOCZY P, AUGUSTIN HG: Angiopoietin-2 sensitizes endothelial cells to TNF-alpha and has a crucial role in the induction of inflammation. Nat Med 12: 235-239, 2006.

FONG KD, TRINDADE MC, WANG Z, NACAMULI RP, PHAM H, FANG TD, SONG HM, SMITH RL, LONGAKER MT, CHANG J: Microarray analysis of mechanical shear effects on flexor tendon cells2. Plast Reconstr Surg 116: 1393-1404, 2005.

GERHARDT H, GOLDING M, FRUTTIGER M, RUHRBERG C, LUNDKVIST A, ABRAMSSON A, JELTSCH M, MITCHELL C, ALITALO K, SHIMA D, BETSHOLTZ C: VEGF guides angiogenic sprouting utilizing endothelial tip cell filopodia. J Cell Biol 161: 1163-1177, 2003.

GOETTSCH W, GRYCZKA C, KORFF T, ERNST E, GOETTSCH C, SEEBACH J, SCHNITTLER HJ, AUGUSTIN HG, MORAWIETZ H: Flow-dependent regulation of angiopoietin-2. J Cell Physiol 214: 491-503, 2008.

GUIDI AJ, BU-JAWDEH G, BERSE B, JACKMAN RW, TOGNAZZI K, DVORAK HF, BROWN LF: Vascular permeability factor (vascular endothelial growth factor) expression and angiogenesis in cervical neoplasia. J Natl Cancer Inst 87: 1237-1245, 1995.

HUDLICKA O, WRIGHT AJ, ZIADA AM: Angiogenesis in the heart and skeletal muscle. Can J Cardiol 2: 120-123, 1986.

HURWITZ H, FEHRENBACHER L, NOVOTNY W, CARTWRIGHT T, HAINSWORTH J, HEIM W, BERLIN J, BARON A, GRIFFING S, HOLMGREN E, FERRARA N, FYFE G, ROGERS B, ROSS R, KABBINAVAR F: Bevacizumab plus irinotecan, fluorouracil, and leucovorin for metastatic colorectal cancer. $N$ Engl J Med 350: 2335-2342, 2004.

JAIN RK: Molecular regulation of vessel maturation. Nat Med 9: 685-693, 2003.

KU DD, ZALESKI JK, LIU S, BROCK TA: Vascular endothelial growth factor induces EDRF-dependent relaxation in coronary arteries. Am J Physiol 265: H586-H592, 1993.

LEE HJ, KOH GY: Shear stress activates Tie2 receptor tyrosine kinase in human endothelial cells. Biochem. Biophys Res Commun 304: 399-404, 2003.

LEE NV, SATO M, ANNIS DS, LOO JA, WU L, MOSHER DF, IRUELA-ARISPE ML: ADAMTS1 mediates the release of antiangiogenic polypeptides from TSP1 and 2. EMBO J 25: 5270-5283, 2006.

LEE S, CHEN TT, BARBER CL, JORDAN MC, MURDOCK J, DESAI S, FERRARA N, NAGY A, ROOS KP, IRUELA-ARISPE ML: Autocrine VEGF signaling is required for vascular homeostasis. Cell 130: 691-703, 2007. 
MAISONPIERRE PC, SURI C, JONES PF, BARTUNKOVA S, WIEGAND SJ, RADZIEJEWSKI C, COMPTON D, MCCLAIN J, ALDRICH TH, PAPADOPOULOS N, DALY TJ, DAVIS S, SATO TN, YANCOPOULOS GD: Angiopoietin-2, a natural antagonist for tie2 that disrupts in vivo angiogenesis. Science 277: 55-60, 1997.

MANDRIOTA SJ and PEPPER MS: Regulation of angiopoietin-2 mRNA levels in bovine microvascular endothelial cells by cytokines and hypoxia. Circ Res 83: 852-859, 1998.

PRIES AR, SECOMB TW, GAEHTGENS P: Structure and hemodynamics of microvascular networks: heterogeneity and correlations. Am J Physiol 269: H1713-H1722, 1995a.

PRIES AR, SECOMB TW, GAEHTGENS P: Design principles of vascular beds. Circ Res 77: 1017-1023, 1995b.

PRIES AR, SCHÖNFELD D, GAEHTGENS P, KIANI MF, COKELET GR: Diameter variability and microvascular flow resistance. Am J Physiol 272: H2716-H2725, 1997.

PRIES AR, SECOMB TW, GAEHTGENS P: Structural adaptation and stability of microvascular networks: theory and simulations. Am J Physiol 275: H349-H360, 1998.

PRIES AR, REGLIN B, SECOMB TW: Remodeling of blood vessels: responses of diameter and wall thickness to hemodynamic and metabolic stimuli. Hypertension 46: 726-731, 2005.

RIVILIS I, MILKIEWICZ M, BOYD P, GOLDSTEIN J, BROWN MD, EGGINTON S, HANSEN FM, HUDLICKA O, HAAS TL: Differential involvement of MMP-2 and VEGF during muscle stretch- versus shear stressinduced angiogenesis. Am J Physiol 283: H1430-H1438, 2002.

SKALAK TC: Angiogenesis and microvascular remodeling: a brief history and future roadmap. Microcirculation 12: 47-58, 2005.

SKALAK TC, PRICE RJ: The role of mechanical stresses in microvascular remodeling. Microcirculation 3: 143-165, 1996.

STYP-REKOWSKA B, DISASSA NM, REGLIN B, ULM L, KUPPE H, SECOMB TW, PRIES AR: An imaging spectroscopy approach for measurement of oxygen saturation and hematocrit during intravital microscopy. Microcirculation 14: 207-221, 2007.

TAYLOR AC, MURFEE WL, PEIRCE SM: EphB4 expression along adult rat microvascular networks: EphB4 is more than a venous specific marker. Microcirculation 14: 253-267, 2007.

TUTTLE JL, HAHN TL, SANDERS BM, WITZMANN FA, MILLER SJ, DALSING MC, UNTHANK JL: Impaired collateral development in mature rats. Am J Physiol 283: H146-H155, 2002a.

TUTTLE JL, SANDERS BM, BURKHART HM, FATH SW, KERR KA, WATSON WC, HERRING BP, DALSING MC, UNTHANK JL: Impaired collateral artery development in spontaneously hypertensive rats. Microcirculation 9: 343-351, 2002b.

WANG HU, CHEN ZF, ANDERSON DJ: Molecular distinction and angiogenic interaction between embryonic arteries and veins revealed by ephrin-B2 and its receptor Eph-B4. Cell 93: 741-753, 1998.

WEIBEL ER, PALADE GE: New cytoplasmic components in arterial endothelia. J Cell Biol 23: 101-112, 1964.

WILLIAMS JL, CARTLAND D, RUDGE JS, EGGINTON S: VEGF trap abolishes shear stress- and overloaddependent angiogenesis in skeletal muscle. Microcirculation 13: 499-509, 2006.

YAMAMOTO K, DE WAARD V, FEARNS C, LOSKUTOFF DJ: Tissue distribution and regulation of murine von Willebrand factor gene expression in vivo. Blood 92: 2791-2801, 1998.

ZAKRZEWICZ A, SECOMB TW, PRIES AR: Angioadaptation: keeping the vascular system in shape. News Physiol Sci 17: 197-201, 2002.

ZAKRZEWICZ A, BONGRAZIO M, KNOCHEL J, STYP-REKOWSKA B, SILVA-AZEVEDO L, PRIES AR: Expression regulation of sprouting inhibitor ADAMTS-1 in vitro allows to predict its expression in the microcirculation of the rat mesentery. J Vasc Res 43: 54, 2006. 